\title{
Experimental displacement trials of the red sea urchin Strongylocentrotus franciscanus (Aggassiz, 1863) (Echinodermata: Echinoidea) at different current velocities
}

\author{
Desplazamiento del erizo de mar Strongylocentrotus franciscanus (Aggassiz, 1863) (Echinodermata: \\ Echinoidea) en condiciones experimentales a diferentes velocidades de corriente
}

\author{
Chita Guisado A. ${ }^{1}$, Luis F. Bückle R. ${ }^{2}$, Mónica Hernández R. ${ }^{2}$ and Daniela Díaz-Guisado ${ }^{3,4}$ \\ ${ }^{1}$ Facultad de Ciencias del Mar y de Recursos Naturales, Universidad de Valparaíso, Valparaíso, Chile. Casilla 5080, \\ Reñaca, Viña del Mar, Chile \\ ${ }^{2}$ Laboratorio de Ecofisiología, Departamento de Acuicultura, Centro de Investigación Científica y Educación Superior \\ de Ensenada (C.I.C.E.S.E.), Km 107 Carretera Tijuana-Ensenada, Ensenada, Baja California, México \\ P.O. Box 434844, San Diego, CA 92143-4844, USA \\ ${ }^{3}$ Instituto de Ciencia y Tecnología, Universidad Arturo Prat. Ejercito 443, Puerto Montt, Chile \\ ${ }^{4}$ Present address: School of Biological Sciences, Victoria University of Wellington, PO Box 600 Wellington 6140, New Zealand \\ chita.guisado@uv.cl
}

\begin{abstract}
Resumen.- El desplazamiento en los animales marinos es afectado por diversos factores ambientales, entre ellos las condiciones hidrodinámicas del medio. En este estudio se evaluó el efecto de la velocidad de corriente sobre el desplazamiento de Strongylocentrotus franciscanus en un canal experimental en condiciones diurnas y nocturnas. Nuestros resultados difieren de estudios previos en la cantidad y la dirección del desplazamiento en estrongilocentrótidos, ya que los erizos se desplazaron a distancias similares en la dirección de la corriente y en contra de la corriente, independientemente de la velocidad de flujo, la distancia diaria que recorrieron fue de aproximadamente $7 \mathrm{~m}$, menor a lo reportado para la misma especie de erizo en British Columbia. La diferencia puede deberse a la ausencia de depredadores o alimento, o bien a las condiciones de los experimentos diurnos y nocturnos. No se observaron diferencias en el desplazamiento durante el día y la noche de $S$. franciscanus.
\end{abstract}

Palabras clave: Velocidad de corriente, movimientos diurno y nocturno, canal experimental

\begin{abstract}
Displacement of marine animals is affected by diverse environmental factors, including hydrodynamics performance. We evaluated the effect of current velocity on the displacement of the sea urchin Strongylocentrotus franciscanus in an experimental flume, in both light and dark conditions. We observed that movement of $S$. franciscanus was directly proportional to the current speed. Our results differ from previous studies in the amount and the direction of displacement of other strongylocentrotids, because sea urchins displacements were similar in the current direction and countercurrent irrespective of current velocity and our results showed displacements of circa $7 \mathrm{~m}$ per day, smaller to that reported for experiments in the same urchin species in British Columbia. The differences may be due to the absence of predators or food, or the trials in day and night conditions. Day and night differences in the displacement of $S$. franciscanus were not observed.
\end{abstract}

Key words: Current speed, day and night movement, experimental flume

\section{Introduction}

Movement patterns are an important factor determining the distribution and size structure of local populations (Palmer et al. 1996). Animals move to locate suitable food sources and habitats, and also to avoid predation, competition (Meadows \& Campbell 1972) and environmental stress (Swingland \& Greenwood 1982).

Displacement is affected by diverse environmental factors, including food availability (James 2000) and hydrodynamics performances, which include currents and waves. The use of hydrodynamic refuges has been reported in freshwater (Cardinale et al. 2002) and marine systems (Arsenault \& Himmelman 1996). Displacement in sea urchins appears to be inversely related to the current velocity (Dance 1987, Kawamata 1998, Dumont et al. 2006) and at shallow depths; wave action may limit urchin grazing (Himmelman et al. 1983). Also, movement patterns of sea urchins are species specific (James, 2000), for example some sea urchins have dial activity patterns and feed at night or there are intra-specific variation in movement foraging behavior (Nelson \& Vance 1979, Glynn et al. 1979, Hay 1984). 
The red sea urchin Strongylocentrotus franciscanus (Aggassiz, 1863) inhabits the exposed coast and protected rocky areas from Alaska, USA to Cedros Island in Baja California, Mexico (Ramírez 2000). Nishizaki \& Ackerman (2007) found that juvenile-adult association in $S$. franciscanus was correlated to the presence of predators and current velocity. The present paper examines the effect of current velocity on the displacement of the red sea urchin $S$. franciscanus.

\section{Material and methods}

The displacement of $S$. franciscanus under different current velocities was evaluated. The red sea urchins $(\mathrm{n}=24$, mean total weight $=285 \pm 19.5 \mathrm{~g}$; mean test diameter $=87.0 \pm 4.09 \mathrm{~cm}$ ) were collected from Bahía de Ensenada, Baja California, Mexico ( $\left.28^{\circ} 0.3^{\prime} \mathrm{N}, 115^{\circ} 19^{\prime} \mathrm{W}\right)$ and transported in sea water in a thermal isolated container covered with macro algae to the Ecophysiology Laboratory (C.I.C.E.S.E.). Immediately after arrival sea urchins were acclimated for two hours in a tank held at the same field temperature to recover from the transport $\left(7 \mathrm{~L} \mathrm{~min}^{-1}\right)$. We identified individual sea urchins with one numbered ring tag attached to one of the large spines.

An experimental flume was used to determine the effect of the current velocity on the displacement of 24 sea urchins. The see-through acrylic tank (flume) was 0.28 $\mathrm{m}$ width by $3 \mathrm{~m}$ length as described by Bückle et $\mathrm{al}$. (2003). A grid pattern was attached on the bottom of the acrylic tanks so movement could be quantified. The photoperiod was maintained in $12 \mathrm{~h}$ light: $12 \mathrm{~h}$ dark with a 30 min transition period. Night measurements were made in a red light environment. We quantified the displacement of 6 urchins in the experimental flume in 4 trials at 4 specific current velocities (0, control, 1.09, 2.9 and $3.09 \mathrm{~cm} \mathrm{~s}^{-1}$ ) and noted the position of each urchin every $5 \mathrm{~h}$ over $25 \mathrm{~h}$. Displacement was quantified measuring the straight-line distance from $0-5 \mathrm{~h}$ till $25 \mathrm{~h}$ and the direction of the movement of the sea urchins $(n=24)$, in the current direction or in the counter-current direction.

We applied a Kruskal-Wallis analysis (one way analysis of variance on ranks) to test differences in displacement between sea urchins exposed to different water flows, to test differences between day and night, counter current and current direction displacement. Dunn's test was used to test for specific differences (Zar 1974).

\section{Results}

The displacement of Stongylocentrotus franciscanus varied according to the current velocity $(\mathrm{H}=11.911$; $3 \mathrm{df}$;
$P=0.008)$. It was lower in the trial with no flow $(57 \mathrm{~cm})$ and several fold greater at $2.9 \mathrm{~cm} \mathrm{~s}^{-1}$ and $3.09 \mathrm{~cm} \mathrm{~s}^{-1}(487.5$ and $350.7 \mathrm{~cm}$ respectively) $(P<0.05)$ (Fig.1).

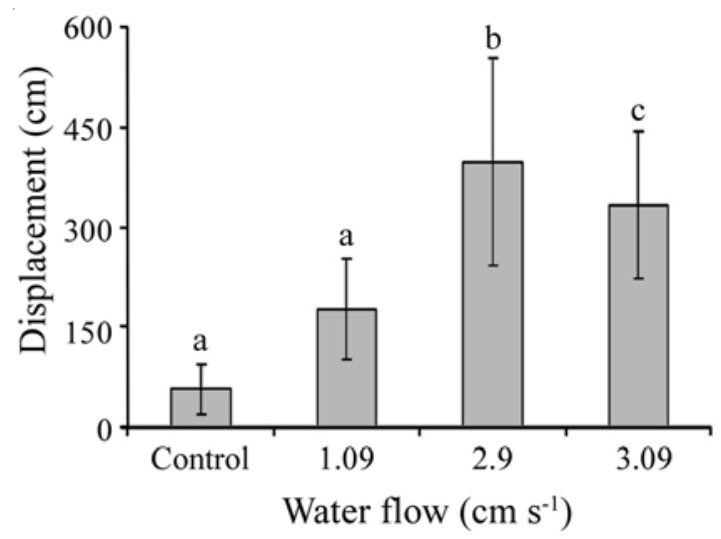

Figure 1

Mean displacement of $S$. franciscanus at different current velocities. Vertical bars represent standard error and different letters indicate significant differences in displacement

Desplazamiento promedio de $S$. franciscanus a diferentes velocidades de corriente. Las barras verticales representan el error estándar y letras diferentes indican diferencia significativa en el desplazamiento

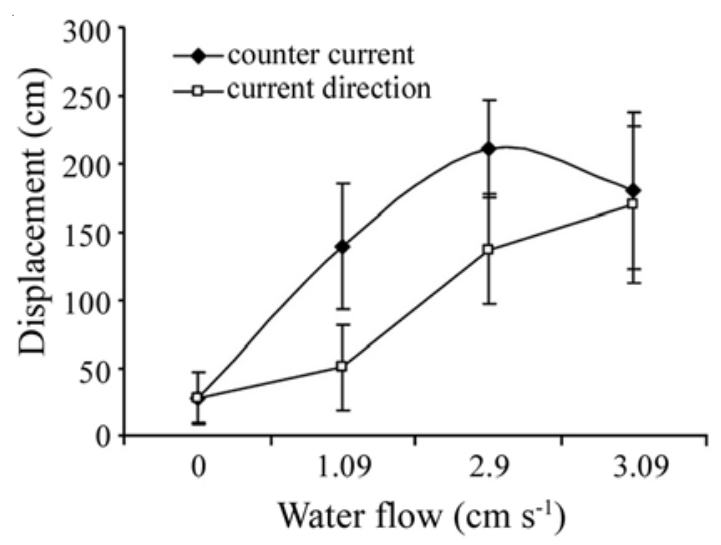

Figure 2

Mean displacement of $S$. franciscanus in the current direction and counter-current. Vertical bars represent standard error

Desplazamiento promedio de $S$. franciscanus a favor y en contra de la corriente. Las barras verticales representan el error estándar 


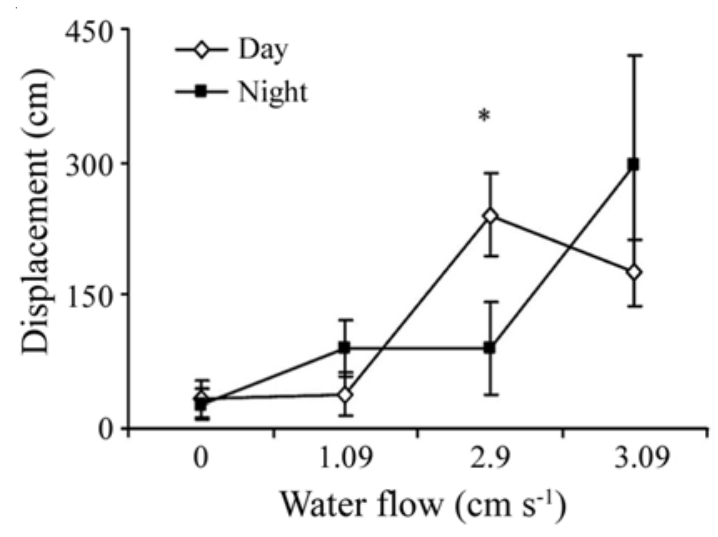

Figure 3

Mean day and night displacement of $S$. franciscanus. Vertical bars represent standard error and * represents significantly different groups

Desplazamiento promedio diurno y nocturno de $S$. franciscanus. Las barras verticales representan el error estándar y * representa grupos significativamente diferentes

Sea urchins moved in the current direction and counter-current independently of the current velocity $(P=0.168$; Fig. 2$)$ and in both, displacement was smaller in the control group and it gradually increased with increasing current velocity up to $2.9 \mathrm{~cm} \mathrm{~s}^{-1}$. Then (3.09 $\mathrm{cm} \mathrm{s}^{-1}$ ) decreased only in the counter-current displacement (Fig. 2). However, at mid velocities (1.09 and $2.9 \mathrm{~cm} \mathrm{~s}^{-1}$ ) the urchins in the current direction moved more than those in counter-current (Fig. 2).

We detected differences in the displacement of the sea urchin between the night and day at all current velocities ( $\mathrm{H}=26.174 ; 7 \mathrm{df} ; \mathrm{P}<0.001)$. The displacement during the day was greater at $2.9 \mathrm{~cm} \mathrm{~s}^{-1}$ than in the control as much during the day $(240.3 \mathrm{~cm} v s .31 .7 \mathrm{~cm})$ as during the night (89.57 cm vs. $25.3 \mathrm{~cm}$ ) (Kruskal Wallis, $P<0.05$ ) (Fig. 3).

\section{Discussion}

The movement of several echinoids appears to be limited by encounters with conspecifics (Dumont et al. 2006). At a high density, sea urchins moved at a slower speed and their net displacement were reduced (Lauzon-Guay et al. 2006). Sea urchins coming into contact with congeners remained stationary for a few seconds and then changed direction (Lauzon-Guay et al. 2006). In our study $S$. franciscanus showed a non-directional displacement that agrees with results of Lauzon-Guay \& Scheibling (2007), this may be attributed to the small space inside the experimental tanks. In addition to limiting the displacement, the confinement of the flume likely increased encounters with congeners.

Sea urchins on barrens can move up to $5 \mathrm{~m}$ per day, and $11 \mathrm{~m}$ in 3 days (Dumont et al. 2006). Coincidently our results showed displacements of $\sim 7 \mathrm{~m}$ per day, smaller than that reported for the same species by Nishisaky \& Ackerman (2007) (0.42 $\mathrm{cm} \mathrm{s}^{-1}$ ) in British Columbia. Kawamata (1998) in laboratory, and Dumont et al. (2006) on barrens, observed that the displacement seemed to be inversely related to current velocity in $S$. nudus and $S$. droebachiensis respectively, being different to our results. We found that the displacement of S. franciscanus was positively correlated to the current speed, except counter current displacement in the $3.09 \mathrm{~cm} \mathrm{~s}^{-1}$ trial. However, the urchins in counter-current moved less than those in direction to the current. This finding may be due to differences in the order of magnitude in current velocities. In our study we did not cover conditions that are often found in the field. Kawamata (1998) using an oscillating flow tank with high velocity current $\left(20-80 \mathrm{~cm} \mathrm{~s}^{-1}\right)$, observed that the rate of movement of $S$. nudus decreased with increasing current velocity with an abrupt decrease beginning at $30 \mathrm{~cm} \mathrm{~s}^{-1}$. In this study the displacement was measured at $1 \mathrm{~min}$ intervals for $10 \mathrm{~min}$. In contrast, we recorded displacement during $25 \mathrm{~h}$ without an oscillating flow. We observed that the sea urchins moved preferably at lower current velocities and that there probably exists a range of velocities that affect the sea urchin behavior. Nishizaki \& Ackerman (2007) explained that the juvenile-adult association in $S$. franciscanus as wave action protection behavior and observed that under high water flow, juvenile $S$. franciscanus sheltered under adults at higher rates than at low flow.

On shorter temporal and spatial scales, many urchins are active during the night as a defense against diurnal predators (Mattison et al. 1977, Nelson \& Vance 1979, Carpenter 1984, Dance 1987). Glynn et al. (1979) point out that in the natural environment the foraging distance of Eucidaris galapagensis is from 1 to $3 \mathrm{~m}$ at night and the displacement is lower during the day. In our study of $S$. franciscanus we did not observe dial changes in displacement, perhaps due to the absence of predators and food.

We did not observe directionality of movement with respect to the direction of the water current. Deviations from a random displacement model likely indicate that local environmental factors (distribution of food patches and physical environmental conditions) influence movement (Dumont et al. 2004). A random walk type of movement is probably the most appropriate strategy for sea urchins, since they move slowly and can likely only 
detect food sources over a limited distance (Zollner \& Lima 1999, Dumont et al. 2007). We concluded that low current velocity (up to $2.9 \mathrm{~cm} \mathrm{~s}^{-1}$ ) does not influence the displacement of $S$. franciscanus, and that were differences between day and night. Possibly, in the presence of predators and food, day/night displacement may show another results.

\section{Acknowledgments}

This work was supported by the Federal Government of Mexico through regular funding of the Centro de Investigación Científica y Educación Superior de Ensenada (CICESE) and by the MECESUP Project UVA 0205 (Chile). We also thank Dr. John Himmelman for his comments and suggestions.

\section{Literature cited}

Arsenault DJ \& JH Himmelman. 1996. Size-related changes in vulnerability to predators and spatial refuge use by juvenile Iceland scallops (Chlamys islandica). Marine Ecology Progress Series 140: 115-122.

Bückle LF, SB Barón, RM Hernández, MA Ledo, AR Solís, EB Pérez \& SA Hernández. 2003. Sistema de temperatura, oxígeno y salinidad para la experimentación en ecofisiología. Hidrobiológica 13(4): 277-287.

Cardinale BJ, MA Palmer \& SL Collins. 2002. Species diversity enhances ecosystem functioning through interspecific facilitation. Nature 415: 426-429.

Carpenter RC. 1984. Predator and population density control of homing behavior in the Caribbean echinoid Diadema antillarum Phillippi. Marine Biology 82: 101-108.

Dance C. 1987. Patterns of activity of the sea urchin Paracentrotus lividus in the Bay of Port-Cros (Var, France, Mediterranean). Marine Ecology 8(2): 131-142.

Dumont C, JH Himmelman \& MP Russell. 2004. Sizespecific movement of green sea urchins Strongylocentrotus droebachiensis on urchin barrens in eastern Canada. Marine Ecology Progress Series 276: 93-101.

Dumont C, JH Himmelman \& MP Russell. 2006. Daily movement of the sea urchin Strongylocentrotus droebachiensis in different subtidal habitats in eastern Canada. Marine Ecology Progress Series 317: 87-99.

Dumont C, JH Himmelman \& SMC Robinson. 2007. Random movement pattern of the sea urchin Strongylocentrotus droebachiensis. Journal of Experimental Marine Biology and Ecology 340: 80-89.

Glynn PW, GM Wellington \& C Birkeland. 1979. Coral reef growth in the Galapagos: limitation by sea urchins. Science 203: 47-49.
Hay ME. 1984. Patterns of fish and urchin grazing on Caribbean coral reefs: are previous results typical?. Ecology 65: 446-454.

Himmelman JH, A Cardinal \& E Bourget. 1983. Community following removal of urchins, Strongylocentrotus droebachiensis, from the rocky subtidal zone of the St. Lawrence estuary, eastern Canada. Oecologia 59: 27-39.

James DW. 2000. Diet, movement, and covering behaviour of the sea urchin Toxopneutes roseus in hydrolith beds in the Gulf of California, México. Marine Biology 137: 913-923.

Kawamata S. 1998. Effect of wave-induced oscillatory flow on grazing by a subtidal sea urchin Strongylocentrotus nudus (A. Agassiz). Journal of Experimental Marine Biology and Ecology 224: 31-48.

Lauzon-Guay JS \& RE Scheibling. 2007. Seasonal variation in movement, aggregation and destructive grazing of the green sea urchin (Strongylocentrotus droebachiensis) in relation to wave action and sea temperature. Marine Biology 151: 2109-2118.

Luazon-Guay JS, RE Scheibling \& MA Barbeau. 2006. Movement patterns in the green sea urchin, Strongylocentrotus droebachiensis. Journal of Marine Biological Association of United Kingdom 86: 167-174.

Mattisson JE, JD Trent, AL Shanks, TB Akin \& JS Pearse. 1977. Movement and feeding activity of red sea urchins urchin - kelp interactions in Nova Scotia. Canadian Journal of Fisheries and Aquatic Science 56: 2300-2314.

Meadows PS \& JI Campbell. 1972. Habitat selection by aquatic invertebrates. Advances in Marine Biology 10: 271-382.

Nelson BV \& RR Vance. 1979. Diel foraging patterns of the sea urchin Centrostephanus coronatus as a predator avoidance strategy. Marine Biology 51: 251-258.

Nishizaki MT \& JD Ackerman. 2007. Juvenile-adult associations in sea urchins (Strongylocentrotus franciscanus and S. droebachiensis): protection from predation and hydrodynamics in S. franciscanus. Marine Biology 151(1): 135-145.

Palmer MA, JD Allan \& CA Butman. 1996. Dispersal as a regional process affecting the local dynamics of marine and stream benthic invertebrates. Trends in Ecology and Evolution 11: 322-326.

Ramírez-Félix E. 2000. Análisis de la extracción de erizo rojo de mar (Strongylocentrotus franciscanus ) según especie clave y conectividad en el área de Santo Tomas a Punta China, Baja California, México. Ciencia Pesquera 14: 19-22.

Swingland IR \& PJ Greenwood. 1982. The ecology of animal movement, 328 pp. Clarendon Press, Oxford, New York.

Zar JH. 1974. Biostatistical analysis, 620 pp. Prentice-Hall, Englewood Cliffs.

Zollner PA \& SL Lima. 1999. Search strategies for landscapelevel interpatch movements. Ecology 80: 1019-1030. 